\title{
PENGARUH CARBON CREDIT, FIRM SIZE, DAN GOOD CORPORATE GOVERNANCE TERHADAP KINERJA PERUSAHAAN PADA PERUSAHAAN MANUFAKTUR YANG TERDAFTAR DI BURSA EFEK INDONESIA
}

\author{
${ }^{a}$ Ni Made Dwi Ratna Sari, bl Gusti Ayu Agung Omika Dewi \\ ${ }^{a, b}$ Fakultas Ekonomi dan Bisnis, Universitas Pendidikan Nasional (Undiknas) Denpasar \\ bomikadewi@undiknas.ac.id
}

\begin{abstract}
The Influence of Carbon Credit, Firm Size, and Good Corporate Governance on Performance of Public Listed Manufacturing Companies. This study aims to examine the effect of carbon credit, firm size, board of commissioners and audit committee on company performance. The population used in this study is manufacturing companies listed on the Indonesia Stock Exchange. The method of sample selection is purposive sampling. Only 25 companies meet the criteria. The hypotheses in this study were tested using $t$ test and $f$ test. The data analysis technique used in this study was multiple linear regression test. The results of the study indicate that carbon credit, firm size, board of commissioners and audit committee partially and simultaneously influence performance of public listed manufacturing companies.
\end{abstract}

Keyword: Carbon credit, firm size, board of commisioners, audit committee

\section{PENDAHULUAN}

Persaingan bisnis dalam industri manufaktur semakin ketat seiring dengan perkembangan perekonomian yang mengakibatkan adanya tuntutan bagi perusahaan untuk terus mengembangkan inovasi, memperbaiki kinerja, dan melakukan perluasan usaha agar dapat terus bertahan dan bersaing. Pada umumnya, tujuan utama sebuah perusahaan adalah untuk mencapai profit tetapi seiring dengan perkembangan zaman, perusahaan berusaha untuk membantu people dan juga menjaga planet secara optimal. Tujuan tersebut dapat dicapai jika perusahaan mempunyai kinerja yang maksimal. Kinerja Perusahaan adalah hal yang sangat penting bagi perusahaan karena kinerja perusahaan yang optimal dapat memudahkan perusahaan dalam mencapai tujuan-tujuan perusahaan seperti mencapai profit optimal, membantu people dan menjaga planet. Secara logika perusahaan yang lebih mapan secarakinerja perusahaanlah yang mampu mencapai profit optimal, yang dapat lebih membantu pihak-pihak lain dan dapat lebih membantu menjaga dunia dari pemanasan global.

Setiap perusahaan yang ada akan berusaha meningkatkan kinerjanya secara maksimal. Untuk itu perlu menganalisis faktor-faktor yang berpengaruh terhadap kinerja perusahaan agar tujuan-tujuan perusahaan dapat tercapai, selain itu isu-isu mengenai profit, people dan planet menarik untuk diteliti dengan proxy carbon credit yang dipreposisikan akan berpengaruh terhadap kinerja perusahaan. Carbon credit disebut juga CER (Certified Emission Reduction). CER diperoleh dengan melakukan pengurangan Green House Gas melalui Clean Development Management. CER yang telah diperoleh perusahaan dapat diperjualbelikan sehingga mendapat pendapatan dari World Bank dan sisi legitimacy theory, perusahaan yang memiliki carbon credit kemungkinan akan lebih didukung oleh para stakeholders khususnya investor dan kreditor sehingga investor dan kreditor akan memberikan pendanaan yang lebih besar kepada perusahaan dengan pendanaan yang dikelola dengan baik maka perusahaan dapat meningkatkan kinerjanya (Sanjaya, 2017). Selain carbon credit, firm size juga merupakan faktor yang akan mempengaruhi kinerja perusahaan. 
Firm size adalah suatu skala dimana dapat diklasifikasikan besar kecilnya perusahaan menurut berbagai cara antara lain dengan total aset, nilai pasar saham, dan lain-lain (Prasetyorini, 2013). Firm size dianggap mampu mempengaruhi kinerja perusahaan karena semakin besar ukuran atau skala perusahaan maka akan semakin mudah bagi perusahaan dalam memperoleh sumber pendanaan, baik yang bersifat internal maupun eksternal (Hery, 11-12:2017).

Good Corporate Governance adalah suatu sistem pengelolaan perusahaan yang dirancang untuk meningkatkan kinerja perusahaan, melindungi kepentingan stakeholders dan meningkatkan kepatuhan terhadap peraturan perundangan - undangan serta nilai - nilai etika yang berlaku secara umum.

Dalam penelitian ini kinerja perusahaan diukur menggunakan Return On Asset (ROA). Menurut Sugiono (2009), Return On Asset (ROA) mengukur tingkat pengembalian dari bisnis atas seluruh aset yang ada atau rasio ini menggambarkan efisiensi pada dana yang digunakan dalam perusahaan. Adapun alasan peneliti menggunakan perusahaan manufaktur sebagai objek penelitian disebabkan karena perusahaan manufaktur yang terdaftar di BEI memiliki jumlah perusahaan terbanyak yang terdiri dari berbagai sub sektor industri sehingga motivasi untuk memperoleh sampel yang cukup dalam penelitian dapat terpenuhi. Penelitian ini menggunakan sampel perusahaan manufaktur dengan klasifikasi basic industry dan chemicals karena industri tersebut paling banyak menghasilkan carbon dibandingkan dengan industri lain. Berdasarkan latar belakang yang telah dipaparkan diatas, peneliti ingin meneliti mengenai Kinerja Perusahaan dengan mengambil judul "Pengaruh Carbon Credit, Firm Size dan Good Corporate Governance terhadap Kinerja Perusahaan pada Perusahaan Manufaktur yang terdaftar di Bursa Efek Indonesia Tahun 2015-2017".

\section{KAJIAN LITERATUR}

\section{Teori Legitimasi}

Menurut Sayekti dan Wondabio (2007), dalam teori legitimasi perusahaan memiliki kontrak dengan masyarakat untuk melakukan kegiatannya berdasarkan nilai-nilai justice, dan bagaimana perusahaan menanggapi berbagai kelompok kepentingan untuk melegitimasi tindakan perusahaan (Citra Dewi dan Sanica, 2017).

Menurut Maryani (2013), gagasan legitimasi bahwa konsep bisnis harus memenuhi persepsipersepsi relevan yang dimiliki oleh publik dan masyarakat luas. Jika perusahaan ingin tetap mendapatkan dukungan dalam masyarakat, perusahaan seharusnya peduli dengan sosial dan lingkungan serta mengungkapkannya dalam annual report (Sanjaya, 2017).

\section{Teori Keagenan}

Menurut Jensen dan Meckling (1976), Teori Agensi menjelaskan hubungan antara principal dengan agent. Hubungan keagenan merupakan hubungan kontrak antara principal yang mempekerjakan agent untuk memberikan suatu jasa dan kemudian mendelegasikan wewenang pengambilan keputusan kepada agent tersebut. Namun adanya perbedaan kepentingan antara principal (stakeholders) dan agent (manajer) menyebabkan munculnya masalah baru. Pendelegasian principal kepada agent membuat pemilik perusahaan tidak dapat mengawasi kinerja manajer, sehingga keputusan manajer kadang tidak sesuai dengan keinginan pemilik perusahaan. Perbedaan kepentingan tersebut dapat mengarah pada tindak kecurangan dan penipuan yang dilakukan agent terhadap principal, yang dikenal dengan istilah moral hazard (Widagdo, 2014).

\section{Kinerja Perusahaan}

Menurut Mwita (2000) pengertian kinerja adalah suatu hasil kerja yang dicapai karena memberikan tujuan strategis perusahaan, kepuasan pelanggan dan kontribusi ekonomi, sedangkan menurut Hyndman \& Anderson (1997) kinerja juga dapat dipandang dari model produksi terdiri dari tiga tahap yaitu input, output dan hasil sehingga kinerja dapat diartikan 
dalam efesiensi dan keefektifan. Menurut Prawirosentono (1997) kinerja adalah hasil kerja yang dapat dicapai oleh seseorang atau sekelompok orang dalam suatu organisasi sesuai dengan wewenang dan tanggungjawab masing-masing, dalam upaya mencapai tujuan organisasi bersangkutan secara legal, tidak melanggar hukum dan sesuai dengan moral maupun etika, sedangkan menurut Waterhaouse \& Svendsen (1998) mendefinisikan kinerja sebagai tindakan-tindakan atau kegiatan yang dapat diukur. Kinerja perusahaan merupakan kemampuan perusahaan dalam mencapai tujuan yang telah ditetapkan (Awantara, 10:2014).

\section{Carbon Credit}

Carbon credit adalah pengurangan emisi gas rumah kaca atau GHG (GreenHouse Gas) emissions yang dapat diperdagangkan dan mempunyai nilai ekonomis dan diciptakan berdasarkan legal framework untuk perdagangan emisi seperti Kyoto Protocol atau EU Emissions Trading Scheme maupun dihasilkan oleh tindakan-tindakan sukarela diluar dari legal frameworks tersebut. Dimana pengertian emisi adalah pelepasan gas-gas yang mengandung karbon ke lapisan atmosfer bumi, pelepasan tersebut terjadi karena adanya proses pembakaran terhadap karbon baik dalam bentuk tunggal atau senyawa dapat berbentuk CO2, CH4, N2O, HFCs, dan lain-lain (Kementerian Lingkungan Hidup 2012 dalam Pratiwi dan Sari 2016). Carbon credit berarti pengurangan emisi yang berbahaya terhadap lingkungan dan dunia (Sanjaya, 2017).

\section{Firm Size (ukuran perusahaan)}

Firm size dapat diartikan sebagai suatu perbandingan besar atau kecilnya usaha dari suatu perusahaan atau organisasi (Sholicah, 2015). Firm size adalah suatu skala dimana dapat diklasifikasikan besar kecilnya perusahaan menurut berbagai cara antara lain dengan total aset, nilai pasar saham, dan lain-lain (Prasetyorini, 2013). Dengan demikian, ukuran perusahaan merupakan ukuran atau besarnya aset yang dimilki oleh perusahaan (Hery, 11 12:2017).

\section{Good Corporate Governance}

Komite Cadbury (Cadbury Report) mengeluarkan definisi tersendiri mengenai GCG, yaitu "prinsip yang mengarahkan dan mengendalikan perusahaan agar mencapai keseimbangan antara kekuatan serta kewenangan perusahaan dalam memberi pertanggungjawabannya kepada para shareholder khususnya, dan stakeholder pada umumnya". Pengertian tersebut digunakan pada konteks untuk mengatur kewenangan Direktur, Manajer, pemegang saham, dan pihak lain yang berhubungan dengan perkembangan perusahaandalam lingkungan tertentu.

Center for European Policy Studies (CEPS) memiliki pemahaman lain yang lebih luas dibanding Cadbury Report mengenai GCG, yaitu sebuah keseluruhan sistem yang dibentuk mulai dari hak (right) yang merupakan kekuatan dari para stakeholder secara individual, proses sebagai mekanisme dari hak - hak tersebut, serta pengendalian yang merupakan mekanisme kemungkinan stakeholder menerima informasi yang diperlukan seputar kegiatan perusahaan, baik di dalam maupun di luar manajemen perusahaan (Ikatan Bankir Indonesia, 245:2017).

\section{Manfaat Penerapan Good Corporate Governance}

Menurut The Forum for Corporate Governance in Indonesia dalam Kustina dan

Zulianto (2017), kegunaan dari Corporate Governance yang baik adalah:
a. Lebih mudah memperoleh modal.
b. Biaya modal (cost of capital) yang lebih rendah.
c. Memperbaiki kinerja usaha.
d. Mempengaruhi harga saham.
e. Memperbaiki kinerja ekonomi. 


\section{Peranan Dewan Komisaris}

Dewan Komisaris memegang peranan yang sangat penting dalam perusahaan, terutama dalam pelaksanaan Good Corporate Governance. Menurut Zehnder (2003) dalam Indra dan Yustiavandana (2006) Dewan Komisaris merupakan inti dari Corporate Governance yang ditugaskan untuk menjamin pelaksanaan strategi perusahaan, mengawasi manajemen dalam mengelola perusahaan, serta mewajibkan terlaksananya akuntabilitas.

\section{Peranan Komite Audit}

Komite Audit memiliki tugas terpisah dalam memantau Dewan Komisaris untuk memenuhi tanggungjawabnya dalam memberikan pengawasan secara menyeluruh. The Institute of Internal Auditors (IIA) merekomendasikan bahwa setiap perusahaan publik harus memiliki Komite Audit yang diatur sebagai komite tetap. Komite Audit beranggotakan Komisaris Independen dan terlepas dari kegiatan manajemen sehari - hari dan mempunyai tanggungjawab utama untuk membantu Dewan Komisaris dalam menjalankan tanggungjawabnya terutama dengan masalah yang berhubungan dengan kebijakan akuntansi perusahaan, pengawasan internal, dan sistem laporan keuangan (Indra dan Yustiavandana, 2006).

\section{Hipotesis Penelitian}

$\mathrm{H}_{1}$ : Carbon Credit berpengaruh positif terhadap Kinerja Perusahaan H2: Firm Size berpengaruh positif terhadap Kinerja Perusahaan

H3: Dewan Komisaris berpengaruh positif terhadap Kinerja Perusahaan H4: Komite Audit berpengaruh positif terhadap Kinerja Perusahaan

\section{METODE}

\section{Populasi dan Sampel Penelitian}

Populasi pada penelitian ini adalah perusahaan manufaktur yang terdaftar di BEI pada tahun 2015-2017. Perusahaan manufaktur industry classification basic industry and chemicals yang terdaftar di BEI pada tahun 2015 - 2017 sebanyak 66 perusahaan, berdasarkan kriteria sampel yang telah ditetapkan diperoleh sebanyak 25 perusahaan yang memenuhi syarat sebagai sampel penelitian dengan periode pengamatan selama 3 tahun dari tahun 2015 2017, sehingga jumlah data yang digunakan adalah sebanyak 75 data.

\section{Teknik Pengumpulan Data}

Teknik pengumpulan data dalam penelitian ini menggunakan metode dokumentasi yaitu metode pengumpulan data yang dilakukan dengan cara mengadakan pencatatan arsip- arsip yang berkaitan dengan objek penelitian.

\section{Teknik Analisis Data}

Data dalam penelitian ini dianalisis dengan statistik deskriptif, kemudian dilakukan pengujian asumsi klasik, pengujian regresi linier berganda, dan pengujian hipotesis. Statistik deskriptif memberikan gambaran tentang distribusi frekuensi variabel-variabel penelitian, nilai maksimum, minimum, rata-rata dan standar deviasi.

\section{Uji Regresi Linier Berganda}

Metode yang digunakan untuk pengujian hipotesis dalam penelitian ini adalah regresi linier berganda. Model regresi linier berganda ditunjukkan pada persamaan berikut ini:

$Y=\alpha+\beta 1 X 1+\beta 2 X 2+\beta 3 X 3+\beta 4 X 4+e$ 


\section{HASIL DAN PEMBAHASAN}

\section{Statistik Deskriptif}

Statistik deskriptif dalam penelitian ini disajikan pada tabel sebagai berikut:

\section{Descriptive}

Statistics

\begin{tabular}{|l|l|l|l|l|l|l|}
\hline & $\mathrm{N}$ & Minimum & Maximum & Mean & $\begin{array}{l}\text { Std. } \\
\text { Deviation }\end{array}$ & Variance \\
\hline $\begin{array}{l}\text { KINERJA PERUSAHAAN } \\
(\mathrm{Y})\end{array}$ & 75 & $\mathbf{. 4 9}$ & $\mathbf{2 3 . 3 3}$ & $\mathbf{6 . 4 7 9 3}$ & $\mathbf{1 . 9 6 5 1 5}$ & $\mathbf{. 6 5 3}$ \\
\hline CARBON CREDIT (X1) & 75 & $\mathbf{. 0 0}$ & $\mathbf{1 . 0 0}$ & $\mathbf{. 2 8 0 0}$ & $\mathbf{. 4 5 2 0 2}$ & .204 \\
\hline FIRM SIZE (X2) & 75 & $\mathbf{2 0 . 5 3}$ & $\mathbf{3 1 . 5 8}$ & $\mathbf{2 6 . 7 2 0 8}$ & $\mathbf{2 . 8 2 0 6 4}$ & $\mathbf{3 . 9 5 6}$ \\
\hline DEWAN KOMISARIS (X3) & 75 & $\mathbf{2}$ & $\mathbf{8}$ & $\mathbf{4 . 3 2}$ & $\mathbf{. 7 7 3 0 7}$ &. $\mathbf{3 0 4}$ \\
\hline KOMITE AUDIT (X4) & 75 & $\mathbf{3}$ & $\mathbf{5}$ & $\mathbf{3 . 1 3}$ & $\mathbf{. 4 1 4 2 8}$ &. $\mathbf{1 7 1}$ \\
\hline Valid N (listwise) & 75 & & & & & \\
\hline
\end{tabular}

Berdasarkan tabel diatas rata-rata Kinerja Perusahaan sebesar 6.4793 dengan standar deviasi sebesar 1.96515. Nilai minimum Kinerja Perusahaan sebesar 0.49 sedangkan nilai maksimum pada sampel yaitu sebesar 23.33 dan nilai varian sebesar 0.653 .

Berdasarkan tabel diatas rata-rata Carbon Credit sebesar 0.2800 dengan standar deviasi sebesar 0.45202. Nilai minimum Carbon Credit sebesar 0.00 sedangkan nilai maksimum pada sampel yaitu sebesar 1.00 dan nilai varian sebesar 0.204.

Berdasarkan tabel diatas rata-rata Firm Size sebesar 26.7208 dengan standar deviasi sebesar 2.82064. Nilai minimum Firm Size sebesar 20.53 sedangkan nilai maksimum pada sampel yaitu sebesar 31.58 dan nilai varian sebesar 3.956.

Berdasarkan tabel diatas rata-rata Dewan Komisaris sebesar 4.32 dengan standar deviasi sebesar 0.77307. Nilai minimum Dewan Komisaris sebesar 2 sedangkan nilai maksimum pada sampel yaitu sebesar 8 dan nilai varian sebesar 0.304.

Berdasarkan tabel diatas rata-rata Komite Audit sebesar 3.13 dengan standar deviasi sebesar 0.41428 . Nilai minimum Komite Audit sebesar 3 sedangkan nilai maksimum pada sampel yaitu sebesar 5 dan nilai varian sebesar 0.171 . 


\section{Uji Normalitas}

One-Sample Kolmogorov-Smirnov Test

\begin{tabular}{|c|c|c|}
\hline 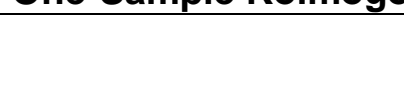 & & $\begin{array}{l}\text { Unstandardized } \\
\text { Residual }\end{array}$ \\
\hline $\mathrm{N}$ & & 75 \\
\hline Normal Parameters $a, b$ & Mean & .0000000 \\
\hline & Std. Deviation & .08485602 \\
\hline Most & Absolute & .078 \\
\hline Extreme & Positive & .078 \\
\hline Differences & Negative & -.057 \\
\hline Kolmogorov-Smirnov Z & & 1.178 \\
\hline Asymp. Sig. (2-tailed) & & .200 \\
\hline
\end{tabular}

Hasil uji Kolmogorov Smirnov menunjukkan bahwa nilai Asymp. Sig. (2-tailed) sebesar 0.200. Nilai ini lebih besar dari signifikan 0.05 sehingga dapat disimpulkan bahwa data mengikuti sebaran normal. Oleh karena itu asumsi normalitas pada regresi telah terpenuhi.

\section{Uji Multikolinearitas}

\begin{tabular}{|l|l|c|}
\multicolumn{1}{c}{} & \multicolumn{2}{c|}{ Coefficients $^{\mathbf{a}}$} \\
\cline { 2 - 3 } \multicolumn{1}{|c|}{ Model } & Collinearity Statistics \\
\cline { 2 - 3 } (Constant) & & VIF \\
\hline CARBON CREDIT (X1) & .947 & $\mathbf{1 . 0 5 6}$ \\
\hline FIRM SIZE (X2) & .969 & $\mathbf{1 . 0 3 2}$ \\
\hline DEWAN KOMISARIS (X3) & .941 & $\mathbf{1 . 0 6 2}$ \\
\hline KOMITE AUDIT (X4) & $\mathbf{. 9 2 6}$ & $\mathbf{1 . 0 7 9}$ \\
\hline
\end{tabular}

Tabel diatas menunjukkan bahwa semua variabel independen Carbon Credit, Firm Size,Dewan Komisaris, dan Komite Audit memiliki nilai VIF yang dihasilkan kurang dari 10 dan nilai tolerance $>10 \%(0.10)$ sehingga dapat disimpulkan bahwa tidak terjadi korelasi ganda (multikolinieritas) antar variabel independen. Oleh karena itu asumsi multikolinieritas telah terpenuhi.

\section{Uji Heteroskedastisitas}

\begin{tabular}{|c|c|c|c|c|c|}
\hline \multirow{2}{*}{$\begin{array}{l}\text { M } \\
\text { od } \\
\text { el }\end{array}$} & & $\begin{array}{l}\text { stand } \\
\text { ardized } \\
\text { Coeffici } \\
\text { ants }\end{array}$ & $\begin{array}{l}\text { Standardized } \\
\text { Coefficients }\end{array}$ & \multirow[t]{2}{*}{$\mathrm{t}$} & \multirow[t]{2}{*}{ Sig. } \\
\hline & $B$ & Std. Error & Beta & & \\
\hline (Constant) & .397 & .832 & & .762 & .448 \\
\hline CARBON CREDIT (X1) & -.159 & .361 & -.050 & -.441 & .661 \\
\hline FIRM SIZE (X2) & .144 & .057 & .283 & 2.512 & .214 \\
\hline DEWAN KOMISARIS (X3) & .030 & .094 & .036 & .318 & .752 \\
\hline KOMITE AUDIT (X4) & -.070 & .399 & -.308 & -2.682 & .209 \\
\hline
\end{tabular}

Tabel diatas menunjukkan bahwa semua variabel bebas yang digunakan memiliki nilai signifikan lebih besar dari 0.05 terhadap absolut residual sehingga dapat disimpulkan bahwa tidak terjadi heteroskedastisitas. 


\section{Uji Autokorelasi}

\begin{tabular}{|l|l|l|l|l|l|}
\multicolumn{7}{|c|}{ Model Summary } \\
\hline Model & $R$ & R Square & $\begin{array}{l}\text { Adjusted } \\
\text { Square }\end{array}$ & $\begin{array}{l}\text { Std. Error of } \\
\text { the } \\
\text { Estimate }\end{array}$ & $\begin{array}{r}\text { Durbin- } \\
\text { Watson }\end{array}$ \\
\hline 1 & $.870^{\mathrm{a}}$ & .757 & .743 & .08174 & $\mathbf{1 . 7 8 0}$ \\
\hline
\end{tabular}

Tabel diatas menunjukan Nilai Durbin Watson (DW) sebesar 1.780. Berdasarkan tabel Durbin-Watson dengan N 75 dan banyak variabel bebas 4 diperoleh nilai upper boung (dU) sebesar 1.705 dan 4-dU sebesar 2.295. Dapat dilihat nilai DW berada di antara batas atau upper boung $(\mathrm{dU})$ dan 4-dU, dengan demikian maka $\mathrm{H}_{\mathrm{o}}$ diterima atau tidak terjadi Autokorelasi.

\section{Uji Regresi Linier Berganda}

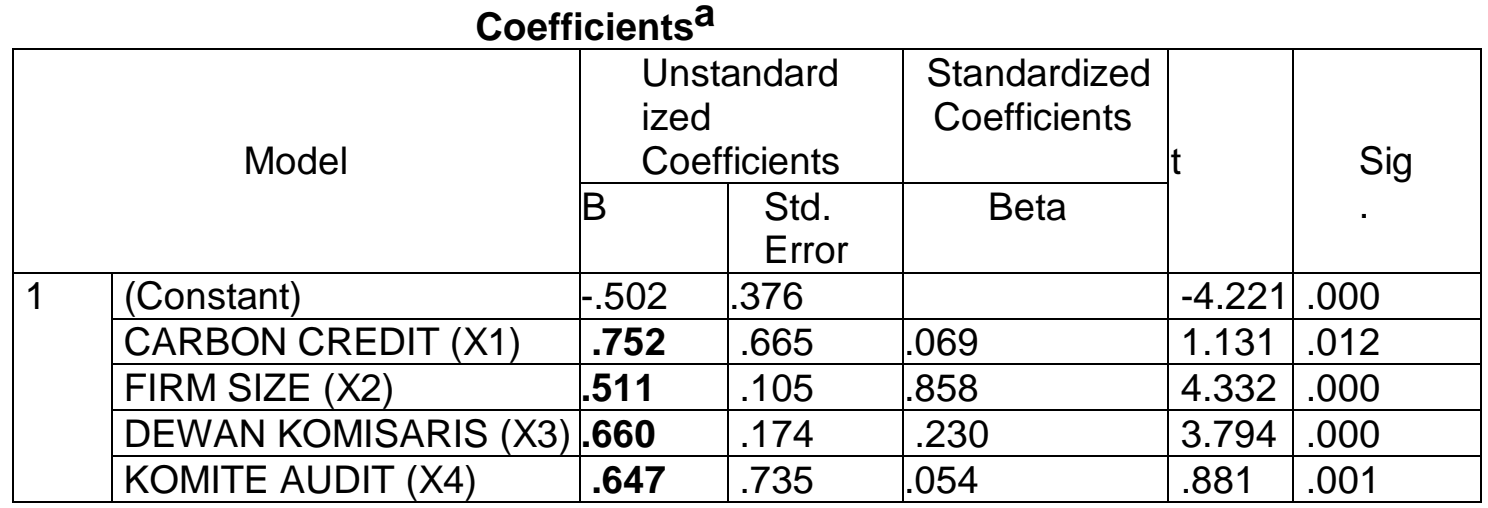

Berdasarkan tabel tersebut diperoleh model regresi berganda yang terbentuk pada penelitian ini adalah sebagai berikut:

\section{$Y=-0.502+0.752 X 1+0.511 X 2+0.660 X 3+0.647 X 4$}

Model ini memiliki interpretasi sebagai berikut:

a) Nilai koefisien Variabel Carbon Credit (X1) sebesar 0.752 , maka artinya apabila nilai Carbon Credit naik satu satuan maka nilai Kinerja Perusahaan akan naik sebesar 0.752. dapat disimpulkan bahwa Carbon Credit Memiliki Pengaruh Positif Terhadap Kinerja Perusahaan.

b) Nilai koefisien Variabel Firm Size (X2) sebesar 0.511, maka artinya apabila nilai Firm Size naik satu satuan maka nilai Kinerja Perusahaan akan naik sebesar 0.511. dapat disimpulkan bahwa Firm Size Memiliki Pengaruh Positif Terhadap Kinerja Perusahaan.

c) Nilai koefisien Variabel Dewan Komisaris (X3) sebesar 0.660, maka artinya apabila nilai Dewan Komisaris naik satu satuan maka nilai Kinerja Perusahaan akan naik sebesar 0.660. dapat disimpulkan bahwa Dewan Komisaris Memiliki Pengaruh Positif Terhadap Kinerja Perusahaan.

d) Nilai koefisien Variabel Komite Audit (X4) sebesar 0.647, maka artinya apabila nilai Komite Audit naik satu satuan maka nilai Kinerja Perusahaan akan naik sebesar 0.647 


\section{Uji Hipotesis}

Koefisien Determinasi $\left(\mathrm{R}^{2}\right)$

Model Summary ${ }^{b}$

\begin{tabular}{|l|l|l|l|l|}
\hline Model & $R$ & R Square & Adjusted R Square & $\begin{array}{l}\text { Std. Error of } \\
\text { the } \\
\text { Estimate }\end{array}$ \\
\hline 1 & $.870^{\mathrm{a}}$ & .757 & $\mathbf{. 7 4 3}$ & .08174 \\
\hline
\end{tabular}

Analisis regresi yang digunakan adalah analisis regresi berganda sehingga koefisien determinasi yang digunakan adalah Adjusted $\mathrm{R}$ square (koefisien determinasi terkoreksi). Nilai koefisien yang diperoleh adalah sebesar 0.743 . Nilai determinasinya menjadi $0.743 \mathrm{x}$ $100 \%=74.3 \%$. Hal ini mengindikasikan bahwa Kinerja Perusahaan dijelaskan $74.3 \%$ oleh Variabel Carbon Credit, Firm Size, Dewan Komisaris, dan Komite Audit sisanya sebesar $25.7 \%$ dijelaskan oleh variabel lain yang tidak dimasukkan ke dalam penelitian.

\section{Uji Hipotesis Simultan (Uji F)}

\begin{tabular}{|c|c|c|c|c|c|c|}
\hline \multicolumn{7}{|c|}{ ANOVA $^{a}$} \\
\hline \multicolumn{2}{|r|}{ Model } & $\begin{array}{l}\text { Sum of } \\
\text { Squares }\end{array}$ & Df & Mean & $F$ & Sig. \\
\hline \multirow[t]{3}{*}{1} & Regression & .689 & 4 & .172 & 14.467 &, $000^{b}$ \\
\hline & Residual & .611 & 70 & .137 & & \\
\hline & Total & 1.300 & 74 & & & \\
\hline
\end{tabular}

Pada Tabel tersebut dapat dilihat nilai signifikan sebesar 0.000 atau $<0,05$ maka menunjukkan bahwa variabel independen yang digunakan yaitu Variabel Carbon Credit, Firm Size, Dewan Komisaris, dan Komite Audit berpengaruh signifikan secara simultan terhadap Kinerja Perusahaan.

Uji Hipotesis Parsial (Uji t)

\section{Coefficients $^{a}$}

\begin{tabular}{|c|c|c|c|c|c|}
\hline \multirow{2}{*}{ Model } & \multicolumn{2}{|c|}{$\begin{array}{l}\text { Unstandardize } \\
\text { d } \\
\text { Coefficients }\end{array}$} & $\begin{array}{l}\text { Standardized } \\
\text { Coefficients }\end{array}$ & \multirow[t]{2}{*}{ t } & \multirow{2}{*}{ Sig. } \\
\hline & $B$ & Std. Error & $\begin{array}{l}\text { Bet } \\
\text { a }\end{array}$ & & \\
\hline 1 (Constant) & -.502 & .376 & & -4.221 & .000 \\
\hline CARBON CREDIT (X1) & .752 & .665 & .069 & 1.131 & .012 \\
\hline FIRM SIZE (X2) & 511 & .105 & .858 & 4.332 & .000 \\
\hline $\begin{array}{l}\text { DEWAN KOMISARIS } \\
\text { (X3) }\end{array}$ & .660 & .174 & .230 & 3.794 & .000 \\
\hline KOMITE AUDIT (X4) & .647 & .735 & .054 & .881 & .001 \\
\hline
\end{tabular}

Adapun hal-hal yang dapat diinterpretasikan dari table tersebut adalah sebagai berikut:

a) Variabel Carbon Credit (X1)

Setelah diuji secara parsial dengan menggunakan uji t, diperoleh nilai sig. sebesar 0.012 . Nilai sig. ini lebih kecil dari 0.05 sehingga dapat disimpulkan bahwa variabel Carbon Credit memiliki pengaruh positif signifikan terhadap Kinerja Perusahaan.

b) Variabel Firm Size (X2)

Setelah diuji secara parsial dengan menggunakan uji t, diperoleh nilai sig. sebesar 0.000 . 
Nilai sig. ini lebih kecil dari 0.05 sehingga dapat disimpulkan bahwa variabel Firm Size memiliki pengaruh positif signifikan terhadap Kinerja Perusahaan.

c) Variabel Dewan Komisaris (X3)

Setelah diuji secara parsial dengan menggunakan uji t, diperoleh nilai sig. sebesar 0.000 .

Nilai sig. ini lebih kecil dari 0.05 sehingga dapat disimpulkan bahwa variabel Dewan

Komisaris memiliki pengaruh positif signifikan terhadap Kinerja Perusahaan.

d) Variabel Komite Audit (X4)

Setelah diuji secara parsial dengan menggunakan uji t, diperoleh nilai sig. sebesar 0.001 . Nilai sig. ini lebih kecil dari 0.05 sehingga dapat disimpulkan bahwa variabel Komite Audit memiliki pengaruh positif signifikan terhadap Kinerja Perusahaan.

\section{Pembahasan \\ Pengaruh Carbon Credit terhadap Kinerja Perusahaan pada Perusahaan Manufaktur yang terdaftar di BEI Tahun 2015-2017}

Hipotesis pertama yang diajukan dalam penelitian ini yaitu Carbon Credit berpengaruh positif terhadap Kinerja Perusahaan pada Perusahaan Manufaktur yang terdaftar di BEI. Berdasarkan hasil penelitian diperoleh nilai koefisien regresi untuk variabel carbon credit dengan nilai signifikan sebesar 0.012. Nilai sig. ini lebih kecil dari

0.05 dengan demikian hipotesis pertama diterima.

Hal ini menunjukkan pengungkapan emisi karbon yang lebih banyak cenderung meningkatkan kinerja keuangan perusahaan. Konsisten dengan teori legitimasi bahwa perusahaan yang memiliki carbon credit akan lebih didukung oleh para stakeholders khususnya investor dan kreditor sehingga investor dan kreditor akan memberikan pendanaan yang lebih besar kepada perusahaan dengan pendanaan yang dikelola dengan baik maka perusahaan dapat meningkatkan kinerjanya (Sanjaya, 2017). Selain itu, perusahaan akan menunjukkan kinerjanya dan memberikan informasi positif yang akan

mendapatkan legitimasi publik dan memberikan perhatian bagi investor yang mana akan meningkatkan kinerja perusahaan. Hasil penelitian ini mendukung hasil penelitian sebelumnya yang dilakukan oleh Chen Kelvin, dkk (2017) yang menyatakan bahwa emisi karbon berpengaruh positif terhadap kinerja perusahaan.

\section{Pengaruh Firm Size terhadap Kinerja Perusahaan pada Perusahaan Manufaktur yang terdaftar di BEI Tahun 2015-2017}

Hipotesis kedua yang diajukan dalam penelitian ini yaitu Firm Size berpengaruh positif terhadap Kinerja Perusahaan pada Perusahaan Manufaktur yang terdaftar di BEI. Berdasarkan hasil penelitian diperoleh nilai koefisien regresi untuk variabel firm size dengan nilai signifikan sebesar 0.000 . Nilai sig. lebih kecil dari 0.05 dengan demikian hipotesis kedua diterima.

Hal ini menunjukkan bahwa semakin besar Firm Size (ukuran perusahaan) semakin mudah bagi perusahaan dalam memperoleh sumber pendanaan, baik yang bersifat internal maupun eksternal dan akan menimbulkan peluang pertumbuhan yang lebih diminati sehingga kinerja perusahaan meningkat. Konsisten dengan teori legitimasi bahwa semakin besar firm size maka investor akan lebih merespon secara positif terhadap perusahaan untuk memberikan pendanaan sehingga pendanaan perusahaan tersebut dapat dikelola dengan menghasilkan keuntungan yang lebih tinggi sehingga kinerja perusahaan akan meningkat. Hasil penelitian ini mendukung hasil penelitian sebelumnya yang dilakukan oleh John William (2017) dan Riki Sanjaya (2017) yang menyatakan bahwa firm size berpengaruh positif terhadap Kinerja Perusahaan.

\section{Pengaruh Dewan Komisaristerhadap Kinerja Perusahaan pada Perusahaan Manufaktur yang terdaftar di BEI Tahun 2015-2017}

Hipotesis ketiga yang diajukan dalam penelitian ini yaitu Dewan Komisaris berpengaruh positif terhadap Kinerja Perusahaan pada Perusahaan Manufaktur yang terdaftar di BEI. Berdasarkan hasil penelitian diperoleh nilai koefisien regresi untuk variabel dewan komisaris 
dengan nilai signifikan sebesar 0.000. Nilai sig. lebih kecil dari

0.05 dengan demikian hipotesis ketiga diterima.

Dengan banyaknya jumlah anggota dewan komisaris, maka pengawasan terhadap manajemen menjadi lebih baik, nasehat dan masukan untuk dewan direksi pun menjadi lebih banyak sehingga kinerja dari manajemen menjadi lebih baik dan dapat meningkatkan kinerja perusahaan. Hasil penelitian ini mendukung hasil penelitian sebelumnya yang dilakukan oleh Dominikus Octavianto Kresno Widagdo (2014) yang menyatakan bahwa dewan Komisaris berpengaruh positif terhadap Kinerja Perusahaan.

\section{Pengaruh Komite Audit terhadap Kinerja Perusahaan pada Perusahaan Manufaktur yang terdaftar di BEI Tahun 2015-2017}

Hipotesis keempat yang diajukan dalam penelitian ini yaitu Komite Audit berpengaruh positif terhadap Kinerja Perusahaan pada Perusahaan Manufaktur yang terdaftar di BEl. Berdasarkan hasil penelitian diperoleh nilai koefisien regresi untuk variabel dewan komisarisdengan nilai signifikan sebesar 0.001. Nilai sig. lebih kecil dari

0.05 dengan demikian hipotesis keempat diterima.

Hal ini menunjukkan bahwa dengan berjalannya fungsi komite audit secara efektif, maka control terhadap perusahaan akan lebih baik, sehingga konflik keagenan yang terjadi akibat keinginan manajemen untuk meningkatkan kesejahteraannya dapat diminimalisasi. Hasil penelitian ini mendukung hasil penelitian sebelumnya yang

dilakukan oleh Muhammad Amien (2011) yang menyatakan bahwa komite audit berpengaruh positif terhadap Kinerja Perusahaan.

\section{SIMPULAN}

Berdasarkan hasil analisis dan pembahasan mengenai Pengaruh Carbon Credit, Firm Size dan Good Corporate Governance terhadap Kinerja Perusahaan pada Perusahan Manufaktur yang terdaftar di Bursa Efek Indonesia tahun 2015-2017, maka dapat ditarik kesimpulan sebagai berikut :

1) Variabel Carbon Credit mempunyai pengaruh yang positif signifikan terhadap Kinerja Perusahaan pada Perusahaan Manufaktur yang terdaftar di BEI tahun 2015-2017, dimana jika Carbon Credit meningkat maka Kinerja Perusahaan akan meningkat juga.

2) Variabel Firm Size mempunyai pengaruh yang positif signifikan terhadap Kinerja Perusahaan pada Perusahaan Manufaktur yang terdaftar di BEI tahun 2015-2017, dimana jika Firm Size meningkat maka Kinerja Perusahaan akan meningkat juga.

3) Variabel Dewan Komisaris mempunyai pengaruh yang positif signifikan terhadap Kinerja Perusahaan pada Perusahaan Manufaktur yang terdaftar di BEI tahun 2015-2017, dimana jika Dewan Komisaris meningkat maka Kinerja Perusahaan akan meningkat juga.

4) Variabel Komite Audit mempunyai pengaruh yang positif signifikan terhadap Kinerja Perusahaan pada Perusahaan Manufaktur yang terdaftar di BEI tahun 2015-2017, dimana jika Komite Audit meningkat maka Kinerja Perusahaan akan meningkat juga.

\section{Saran}

Berdasarkan simpulan diatas, ada beberapa saran yang dapat penulis berikan yang berkaitan dengan hasil penelitian dan hasil pembahasan dalam penelitian ini adalah:

Bagi investor, ROA menjadi salah satu faktor penting untuk melihat kinerja perusahaan. Karena ROA menggambarkan sejauh mana kemampuan aset-aset yang dimiliki perusahaan bisa menghasilkan laba. Dengan mengetahui tingkat ROA, investor dapat mengetahui tingkat pengembalian atas dana yang telah diinvestasikan. Selain itu, investor juga perlu mempertimbangkan kredibilitas perusahaan di masa mendatang dan juga faktor- faktor lain yang dapat mempengaruhi kinerja perusahaan.

Bagi perusahaan, pengungkapan emisi karbon dan penerapan Good Corporate Governance 
(GCG) seperti dewan komisaris dan komite audit yang sesuai akan memberikan peningkatan kinerja keuangan perusahaan yang ditunjukkan dengan meningkatnya ROA. Selain itu, perusahaan akan lebih mudah untuk menarik investor guna berinvestasi pada perusahaan, sehingga akan memiliki kesempatan dalam memperoleh return dari kegiatan investasi tersebut. Selain itu juga, dengan diterapkannya GCG akan memberikan citra baik bagi perusahaan.

Peneliti selanjutnya diharapkan dapat melakukan penelitian dengan menambah variabelvariabel lain yang diprediksikan mampu meningkatkan kinerja perusahaan, misalnya ukuran dewan direksi, kepemilikan manajerial, kepemilikan institusional, kualitas audit dan lainnya.

\section{REFERENSI}

Amien, Muhammad. 2011. "Pengaruh Good Corporate Governance Terhadap Kinerja Keuangan Pada Perusahaan Perbankan Yang Terdaftar Di BEI." Universitas Pembangunan Nasional Veteran.

Awantara, I. Gusti Putu Diva. 2014. Sistem Manajemen Lingkungan. Yogyakarta: Deepublish.

Bursa Efek Indonesia. www.idx.co.id

Dewi, Kadek Ria Citra dan Sanica, I Gede. 2017. "Pengaruh Kepemilikan Institusional, Kepemilikan Manajerial, Dan Pengungkapan Corporate Social Responsibility Terhadap Nilai Perusahaan Pada Perusahaan Manufaktur Yang Terdaftar Di Bursa Efek Indonesia". Jurnal Akuntansi dan Bisnis Vol. 2 No.1

Ghozali, Iman. 2016. Aplikasi Analisis Multivariete IBM SPSS 23. Edisi 8. Semarang: Universitas Diponegoro.

Hery. 2017. Kajian Riset Akuntansi. Jakarta: Gramedia Widiasarana.

Indra, Surya and Ivan Yustiavandana. 2006. Penerapan Good Corporate Governance: Mengesampingkan Hak-Hak Istimewa Demi Kelangsungan Usaha. Universitas Indonesia: Kencana.

Indonesia, Ikatan Bankir. 2017. Memahami Audit Intern Perbankan (Ed. Revisi). Jakarta: Gramedia Pustaka Utama

Kelvin, Chen, Fransiskus E. Daromes, and Suwandi Ng. 2017. "Pengungkapan Emisi Karbon Sebagai Mekanisme Peningkatan Kinerja Untuk Menciptakan Nilai Perusahaan." Jurnal Dinamika Akuntansi, Keuangan Dan Perbankan Vol.6(No. 1):1-18.

Komite Nasional Kebijakan Governance (KNKG). 2006. "Pedoman Umum Good Corporate Governance Indonesia." (http:///www.knkg-indonesia.com). diakses 5 September 2018

Kustina, Ketut Tanti dan Zulianto, Devi Leviyanthie. 2017. "Peran Audit Internal Dan Komitmen Manajemen Dalam Penerapan Good Corporate Governance." Jurnal IImiah Akuntansi dan Bisnis Vol. 2 No. 1

Naja, Hasanuddin Rahman Daeng. 2004. Manajemen Fit \& Proper Test. Yogyakarta: Pustaka Widyatama.

Sanjaya, Riki. 2017. "Carbon Credit Dan Faktor-Faktor Lain Yang Berpengaruh Terhadap Kinerja Perusahaan Pada Perusahaan Manufaktur." Jurnal Bisnis Dan Akuntansi Vol. 9:No. 2.

Sugiyono. 2007. Metode Penelitian Kuantitatif Kualitatif Dan R\&D. Bandung: Alfabeta. Widagdo, Dominikus Octavianto Kresno. 2014. "Pengaruh Good Corporate Governance Terhadap Kinerja Perusahaan." Jurnal Akuntansi Vol.3:No.3.

William, John. 2017. "Faktor - Faktor Yang Mempengaruhi Kinerja Perusahaan Pada Perusahaan Yang Terdaftar Di Bursa Efek Indonesia." Jurnal Bisnis Dan Akuntansi Vol. 19:No. 1a. 